\title{
Peningkatan Ketahanan Pangan Masyarakat Sekitar Hutan di KHDTK Mungku Baru di Masa Pandemi Covid-19
}

\author{
Improving Food Security of Communities Around the Forest at KHDTK Mungku Baru during \\ the Covid-19 Pandemic
}

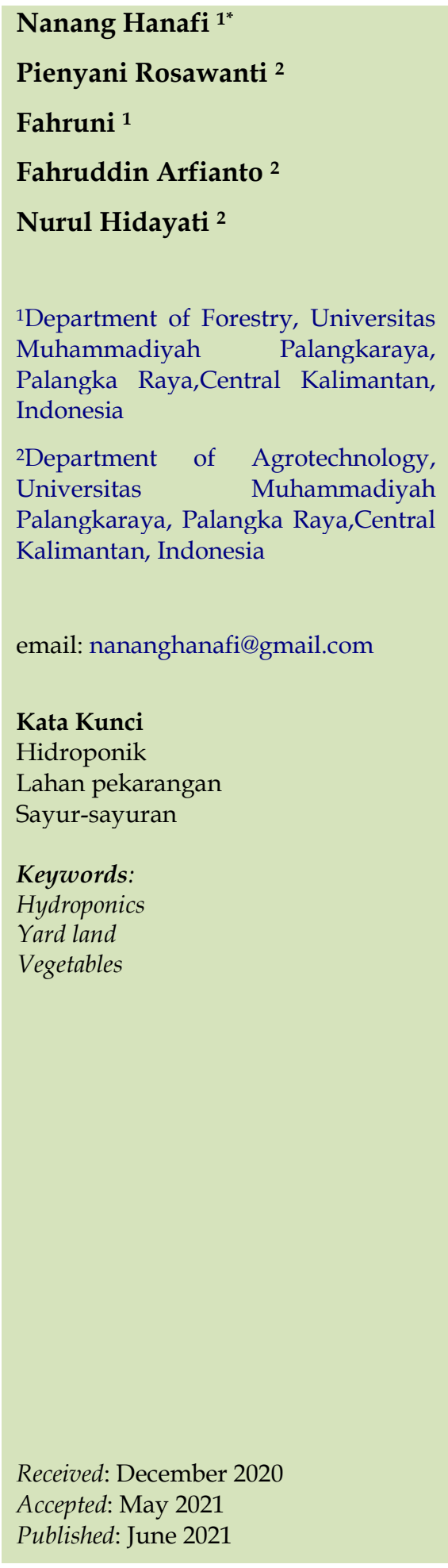

\begin{abstract}
Abstrak
Hidroponik merupakan metode bercocok tanam tanpa menggunakan media tanah, melainkan dengan larutan mineral bernutrisi atau bahan lainnya, Media yang digunakan termasuk limbah rumah tangga, seperti botol, ember, selang, pot, paralon, sumbu kompor dan barang rumah tangga lain. Teknik ini dapat di aplikasikan pada lahan pekarangan rumah untuk menghasilkan sayuran bagi keluarga. Tujuan pengabdian adalah masyarakat Kelurahan Mungku Baru mampu mengoptimalkan lahan pekarangan untuk budidaya tanaman pertanian dengan sistem hidroponik rakit apung maupun duck bucket untuk meningkatkan ketahanan pangan di masa pandemi covid-19 dan pasca covid-19. Kegiatan dilaksanakan di Kelurahan Mungku Baru Kecamatan Rakumpit Kota Palangka Raya pada bulan Agustus 2020. Metode kegiatan dengan penyuluhan dan workshop atau kegiatan penyuluhan dan praktek pembuatan hidroponik sederhana secara statis, yaitu dengan menjelaskan teknik budidaya hidroponik sederhana langsung serta memperagakannya, dan peserta kegiatan diberikan pamflet budidaya hidroponik sederhana sebagai panduan di rumah. Hasil kegiatan masyarakat dapat menyiapkan tempat hidroponik, penyiapan media hidup tanaman, menyemai bibit, menanam bibit dan membuat larutan hidroponik secara langsung, serta mereka mengetahui dosis penggunaan larutan nutrisi hidroponik dalam pengaplikasiannya. Masyarakat melakukan budidaya sayuran dengan metode hidroponik sederhana yang diletakkan di teras dan pekarangan rumah dengan jenis sayuran yang mudah ditanam, cepat panen dan mudah dalam pemeliharaannya.
\end{abstract}

\begin{abstract}
Hydroponics is a method of growing crops without using soil media but with a nutrient solution of minerals or other materials. The media used includes household waste, such as used bottles, buckets, hoses, pots, paralon, stove wicks, and other household items. This technique can be applied to the yard of the house to produce vegetables for the family. The purpose of the service is that the Mungku Baru Village Community can optimize their yards for agricultural crop cultivation using a floating raft hydroponic system and duck bucket to improve food security during the Covid-19/post-covid-19 pandemics. The activity was carried out in Mungku Baru Village, Rakumpit District, Palangka Raya City in August 2020. The method of this activity is by way of counseling and workshops or extension activities, and the practice of making simple hydroponics statically, namely by explaining simple hydroponic cultivation techniques directly and demonstrating them, and activity participants are given simple hydroponic cultivation pamphlets as a guide to hydroponic techniques in their homes. As a result of this activity, the community has prepared a hydroponic place, followed by preparing plant life media, sowing seeds, planting seeds, and making hydroponic solutions directly. They know the dosage of using the hydroponic nutrient solution in its application. The community cultivates vegetables with a simple hydroponic method placed on the terraces and yards of the house with vegetables that are easy to grow, harvest quickly, and easy to maintain.
\end{abstract} under the CC-BY-SA License (http://creativecommons.org/licenses/by-sa/4.0/). DOI: https:// doi.org/10.33084/pengabdianmu.v6i4.1924 


\section{PENDAHULUAN}

Kelurahan Mungku Baru merupakan salah satu kelurahan di Kecamatan Rakumpit Kota Palangka Raya. Luas Area Kelurahan Mungku Baru sebesar 193, 36 km² dengan jumlah penduduk \pm 672 jiwa dengan laju pertumbuhan penduduk sebesar 1,97\%. Sebagian besar masyarakat Mungku Baru menggantungkan hidupnya dengan bekerja sebagai petani. Bertani atau berladang merupakan mata pencaharian pokok masyarakat disamping mata pencaharian sampingan berupa mencari ikan di sungai, bekerja sebagai penambang emas dan pasir puya, dan berburu satwa. Masyarakat Mungku Baru sangat bergantung pada keberadaan hutan. Bagi masyarakat Mungku Baru, hutan merupakan tempat penyedia sebagian kebutuhan mereka, misalnya tempat atau lahan untuk berladang, penghasil hasil hutan bukan kayu (HHBK) yang dapat dimanfaatkan oleh masyarakat seperti kulit gamor, madu, getah damar, obat-obatan tradisional dan lain sebagainya (Hanafi et al., 2017).

Kawasan hutan di Kelurahan Mungku Baru berdasarkan SK Menteri Kehutanan Republik Indonesia Kehutanan Nomor 611/Menhut-II/2014 tanggal 08 Juli 2014 tentang Penetapan Kawasan Hutan Dengan Tujuan Khusus sebagai Hutan Pendidikan pada Kawasan Hutan Produksi Tetap di Kota Palangka Raya Provinsi Kalimantan Tengah seluas \pm 4.910 ha. Masyarakat Mungku Baru memanfaatkan KHDTK untuk mencari kopal, dimana kopal ini merupakan salah satu produk hhbk yang potensial di KHDTK, obat-obat yang berasal dari tumbuhan hutan, berburu satwa misalnya babi hutan, burung, dan lain-lain. Kendala masyarakat dalam mengelola kopal adalah rendahnya harga jual kopal ke pengepul-pengepul sehingga masyarakat tidak tertarik untuk mengusahakan kopal sebagai mata pencaharian mereka (Resmeiliana et al., 2014).
Sistem pertanian yang dipraktekkan oleh masyarakat Mungku Baru masih sangat tradisional, masyarakat melakukan kegiatan tebas bakar untuk membuka lahan untuk ditanami tanaman holtikultur seperti jagung dan padi. Dengan berkurangnya areal hutan yang dapat dikonversi menjadi ladang oleh masyarakat, akan menimbulkan keresahan dan kecemasan masyarakat di sekitar hutan (Kusumaningtyas \& Chofyan, 2013). Beberapa tahun terakhir Kalimantan Tengah mengalami bencana kebakaran hutan dan lahan. Kebakaran hutan dan lahan yang terjadi selama ini dipercaya sebagian besar disebabkan oleh masyarakat yang membakar lahan mereka untuk dijadikan kebun. Selain itu juga keluar Peraturan Gubernur Kalimantan Tengah No. 49 Tahun 2015 tentang Pencabutan Atas Peraturan Gubernur Kalimantan Tengah No. 52 Tahun 2008 tentang Pedoman Pembukaan Lahan dan Perkarangan Bagi Masyarakat di Kalimantan Tengah dan Peraturan Gubernur Kalimantan Tengah No. 15 Tahun 2010 tentang Perubahan Atas Peraturan Gubernur Kalimantan Tengah No. 52 Tahun 2008 tentang Pedoman Pembukaan Lahan dan Perkarangan bagi Masyarakat di Kalimantan Tengah. Dengan berlakunya peraturan tersebut di atas, maka masyarakat dilarang untuk membakar hutan dan lahan untuk kegiatan pembukaan lahan. Hal ini tentunya akan berdampak bagi kondisi masyarakat Mungku Baru, ketika kegiatan pertanian dilarang untuk membakar lahan, pelarangan penambangan emas secara illegal, pelarangan penggunaan racun dan strum dalam mencari ikan, dan kegiatan ilegal lainnya. Keresahan dan kecemasan masyarakat Mungku Baru jika tidak dilakukan pendekatan secara persuasif akan menimbulkan konflik sosial masyarakat Mungku Baru.

Pandemi Covid-19 yang terjadi saat ini tidak hanya berpengaruh terhadap aktivitas sosial masyarakat, tetapi juga berpengaruh terhadap sektor pangan. Organisasi 
Pangan dan Pertanian Dunia atau Food and Agriculture Organization/FAO memperkirakan adanya bencana kelaparan yang melanda penduduk dunia karena pandemi Covid-19 (Jusriadi et al., 2020).

Selama ini untuk memenuhi kebutuhan hidup seharihari misalnya beras, sayur mayur, dan lauk pauk, masyarakat Mungku Baru harus membeli di Pasar Besar Kota Palangka Raya dengan menempuh jarak kurang lebih 45 menit sampai 1 jam menggunakan transportasi kelotok, kemudian dilanjutkan lagi $\pm 1,5$ jam transportasi darat menuju pasar besar. Tingginya biaya transportasi yang dikeluarkan masyarakat untuk memenuhi kebutuhan sehari-hari berdampak pada harga jual bahan baku yang tinggi di Kelurahan Mungku Baru. Sehingga tidak jarang masyarakat yang kurang sejahtera mengandalkan hutan untuk mencari berbagai sayuran yang ada di dalam hutan (Purnama \& Afitah, 2021). Kawasan hutan secara tradisional diketahui sebagai penghasil hasil butan bukan kayu termasuk bahan pangan bagi masyarakat sekitar hutan. Penelitian dari Dwiprabowo et al. (2011) menerangkan bahwa produksi pangan dari kawasan hutan cenderung berfluktuasi dari tahun ke tahun, kontribusi produksi komoditas pangan (padi, jagung, kacang-kacangan) dari kawasan hutan menyumbang kurang dari satu persen dari total produksi Provinsi Jawa Barat.

Trimester pertama Indonesia Tahun 2020 mengalami wabah Covid-19 yang disebabkan oleh coronavirus. Coronavirus merupakan keluarga besar virus yang menyebabkan penyakit pada manusia dan hewan. Pada manusia biasanya menyebabkan penyakit infeksi saluran pernapasan, mulai flu biasa hingga penyakit yang serius seperti Middle East Respiratory Syndrome (MERS) dan Sindrom Pernafasan Akut Berat/Severe Acute Respiratory Syndrome (SARS) (Yuliana, 2020). Coronavirus jenis baru yang ditemukan pada manusia sejak kejadian luar biasa muncul di Wuhan Cina, pada
Desember 2019, kemudian diberi nama Severe Acute Respiratory Syndrome Coronavirus 2 (SARS-CoV-2), dan menyebabkan penyakit Coronavirus Disease-2019 (Covid-19) (Zheng, 2020). Ditambah wabah corona yang melanda Indonesia, dimana Kota Palangka Raya termasuk dalam zona merah untuk Provinsi Kalimantan Tengah, sehingga masyarakat merasakan ketakutan akan penyebaran wabah corona, dan takut untuk belanja bahan pokok ke Pasar Besar Kota Palangka Raya. Tujuan pengabdian ini adalah agar Masyarakat Kelurahan Mungku Baru mampu mengoptimalkan lahan pekarangan untuk budidaya tanaman pertanian menggunakan system hidroponik rakit apung maupun duck bucket untuk meningkatkan ketahanan pangan di masa pandemi covid-19 dan pasca covid-19.

\section{METODOLOGI}

Kegiatan Pengabdian Kepada Masyarakat dilaksanakan di Kelurahan Mungku Baru Kecamatan Rakumpit Kota Palangka Raya pada bulan Agustus 2020. Metode kegiatan pengabdian ini dengan cara penyuluhan dan workshop atau kegiatan penyuluhan dan praktek pembuatan hidroponik sederhana secara statis, yaitu dengan cara: menjelaskan teknik budidaya hidroponik sederhana langsung serta memperagakannya, dan peserta kegiatan diberikan pamflet budidaya hidroponik sederhana sebagai panduan tekhik hidroponik di rumah mereka. Pelaksanaan kegiatan pengabdian kepada masyarakat dilakukan dalam bentuk sosialisasi dan pelatihan. Sosialisasi tentang pengenalan hidroponik secara ringkas, penggunaan nutrisi untuk menunjang pertumbuhan Tanaman.

\section{HASIL DAN PEMBAHASAN}

Kegiatan pelatihan dilaksanakan dalam beberapa tahapan kegiatan. Tahapan pelaksanaan adalah sebagai berikut: 


\section{Persiapan kegiatan.}

Tahapan persiapan kegiatan adalah sebagai berikut:

a. Penyediaan media tanam. Media tanam yang digunakan dalam kegiatan ini adalah rockwool dan styrofoam.

b. Penyediaan bahan dan peralatan. Bahan yang digunakan dalam kegiatan sosialisasi dan pelatihan ini antara lain: benih tanaman dan nutrisi hidroponik AB-Mix. Benih tanaman yang digunakan adalah kangkung, bayam dan sawi. Peralatan yang digunakan: ember box bekas es krim, netpot, kain flannel, box plastik besar untuk media rakit apung, styrofoam/gabus yang dilubangi yang bertujuan untuk untuk mengapungkan bibit tanaman, Total Dissolved Solids (TDS) dan $\mathrm{pH}$ meter untuk pengukuran kualitas air, kawat untuk pelubang, kompor untuk memanaskan kawat, gelas ukur untuk menakar jumlah nutrisi dan air baku yang digunakan.

c. Penyemaian bibit. Ada beberapa benih yang harus disemai terlebih dahulu seperti sawi dan tomat. Sedangkan benih kangkung dan bayam tidak perlu disemai tapi langsung ditanam dengan cara ditabur.

2. Kegiatan Sosialisasi dan Pelatihan

a. Kegiatan Sosialisasi meliputi: Pengenalan dan macam Hidroponik; Pengenalan Media Tanam Hidroponik; Pengenalan Nutrisi Hidroponik

b. Pembuatan Nutrisi Hidroponik dan Penggunaan Nutrisi Hidroponik. Dalam sesi ini dilakukan kegiatan pelatihan peracikan nutrisi dan juga bagaimana cara penggunaan nutrisi sesuai dengan tanaman yang kita semai.

c. Penyemaian Bibit Tanaman. Pelatihan langsung bagaimana menyemaikan bibit tanaman pada media tanam. d. Pindah Tanam Bibit yang Siap Tanam. Kegiatan ini mengajarkan kepada masyarakat bagaimana cara melubangi ember plastik dan styrofoam/gabus untuk pindah semai ke media tanam, selain itu juga mengajarkan bagaimana memindahkan semai tanaman yang sudah dilakukan \pm 1 bulan sebelumnya ke ember plastik dan box plastik rakit apung.

3. Monitoring dan Evaluasi Kegiatan Masyarakat

a. Pemeliharaan Tanaman meliputi kegiatan:

1) Pengukuran $\mathrm{pH}$ dan nutrisi tanaman. $\mathrm{pH}$ penting diketahui untuk mengatur serapan unsur hara tanaman agar tidak terjadi defisiensi. Kadar nutrisi dalam larutan dapat diukur dengan TDS atau Parts Per Millions (PPM). Hasil pengukuran menunjukkan nilai EC larutan yang sangat menentukan kecepatan metabolisme tanaman yaitu jika nutrisi yang diberikan sesuai dengan kebutuhan tanaman.

2) Pengendalian hama dan penyakit. Hama yang sering menyerang tanaman hidroponik adalah kutu putih, kutu Aphid, siput, lalat pengorok daun dan semut. Jenis penyakit pada tanaman hidroponik umumnya sama dengan tanaman yang dibudidayakan di tanah. Penyebab penyakit disebabkan oleh jamur, bakteri dan virus yang ditularkan melalui vektor serangga ataupun penggunaan alat-alat tanam yang terkontaminasi. Pada kegiatan budidaya secara hidroponik ini tidak ditemukan adanya hama dan penyakit, hal ini karena benih yang digunakan adalah benih yang bersertifikat dan kebutuhan nutrisi tanaman cukup untuk pertumbuhan dan perkembanagan tanaman. 
b. Kegiatan Pemanenan dan Pasca Panen. Kegiatan ini memberi pemahaman kepada masyarakat kapan tanaman hidroponik dapat dipanen, dan bagaimana cara pemanenannya, dan kegiatan pasca panen. Masyarakat dilatih mengenali tanda-tanda tanaman bisa dipanen yaitu dengan mengetahui umur panen sesuai deskripsi tanaman yang dibudidayakan. Kemudian bagaiman cara memanen sayuran yang benar, sayuran bisa dipetik atau dipotong dengan menggunakan pisau. Setelah sayuran dipanen, dibersihkan dan disimpan di tempat yang bersih. Masyarakat sasaran kegiatan pengabdian ini adalah masyarakat Mungku Baru terutama yang tidak memanfaatkan pekarangan rumah untuk pemenuhan kebutuhan pangan. Masyarakat belum mengoptimalkan fungsi pekarangan sebagai budidaya sayuran. Teknik budidaya tanaman sayuran secara hidroponik diperkenalkan kepada masyarakat dalam upaya pemanfaatan pekarangan yang luas maupun sempit dalam arti bisa dilakukan atau ditempatkan di teras rumah. Sebagian masyarakat beranggapan bahwa budidaya hidroponik membutuhkan dana yang nahal. Pada kegiatan ini Tim Pengabdian menjelaskan teknik budidaya hidroponik secara sederhana dan dapat menggunakan barang-barang bekas rumah tangga yang tidak dipergunakan lagi seperti bekas botol minuman mineral, ember cat, kaleng susu, kaleng biskuit dan lain sebagainya. Masyarakat sangat antusias dan menyambut positif kegiatan ini karena mudah dilakukan dan bisa dilakukan di rumah.

Pada kegiatan ini masyarakat diminta langsung mempraktekkan cara membuat nutrisi hidroponik untuk tanaman sayuran, menyiapkan media tanam, memberi nutrisi atau pupuk untuk tanaman dan menyemai benih sayuran. Kemudian tanaman hiroponik dipelihara sampai panen. Cara pemeliharaan tanaman juga dijelaskan terutama pemberian nutrisi pada saat tanaman sudah mulai tumbuh dan berkembang. Dijelaskan juga jangan sampai tanaman kekurangan nutrisi tanaman sampai panen.

Kegiatan monitoring dilakukan oleh Tim Pengabdian menjelang panen tanaman sayuran hidroponik yaitu kangkung dan bayam. Tim pengabdian menjelaskan cara panen yang baik dan benar serta penyimpanan hasil panen sayuran supaya kualitas sayuran yang dipanen tetap baik. Pada kegiatan monitoring ini juga terlihat di beberapa rumah sudah melakukan teknik budidaya sayuran hidroponik secara hidroponik. Adanya budidaya sayuran di pekarangan diharapkan dapat memenuhi kebutuhan pangan terutama sayur-sayuran untuk masyarakat Mungku Baru sehingga dapat mengurangi ketergantungan kebutuhan sayur-sayuran dari daerah lain dan masyarakat bisa mandiri pangan. Sistem ketahanan pangan terdiri dari tiga subsistem, yaitu ketersediaan, keterjangkauan dan pemanfaatan pangan (Suryana, 2014). Kegiatan berupa sosialisasi dan pelatihan sangat efektif dengan meminta masyarakat langsung mempraktekkan dan mengaplikasikan langsung materi yang diberikan seperti pada sosialisasi dan pelatihan budidaya hidroponik yang dilakukan oleh Hidayati et al. (2016) di Kelurahan Tanjung Pinang Kecamatan Pahandut Kota Palangka Raya. Budidaya hidroponik sayuran di pekarangan dapat mendukung ketahanan pangan terutama di masa pandemi Covid-19.

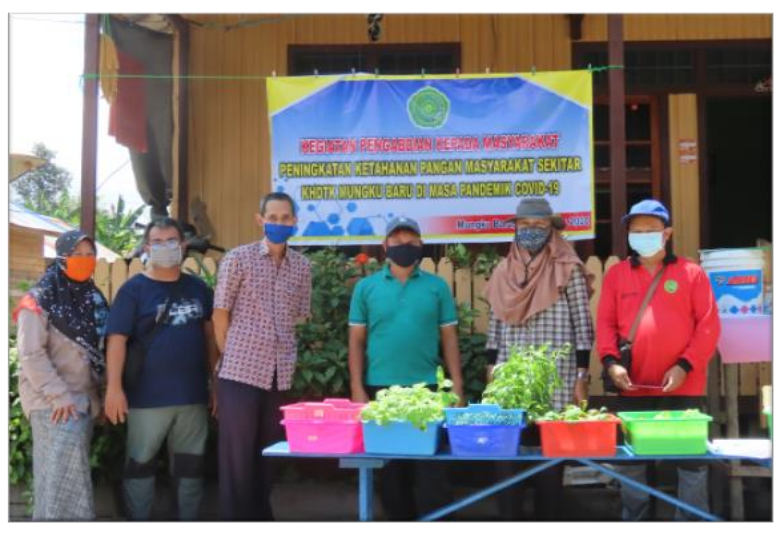

Gambar 1. Tim Pengabdian dan masyarakat Mungku Baru 


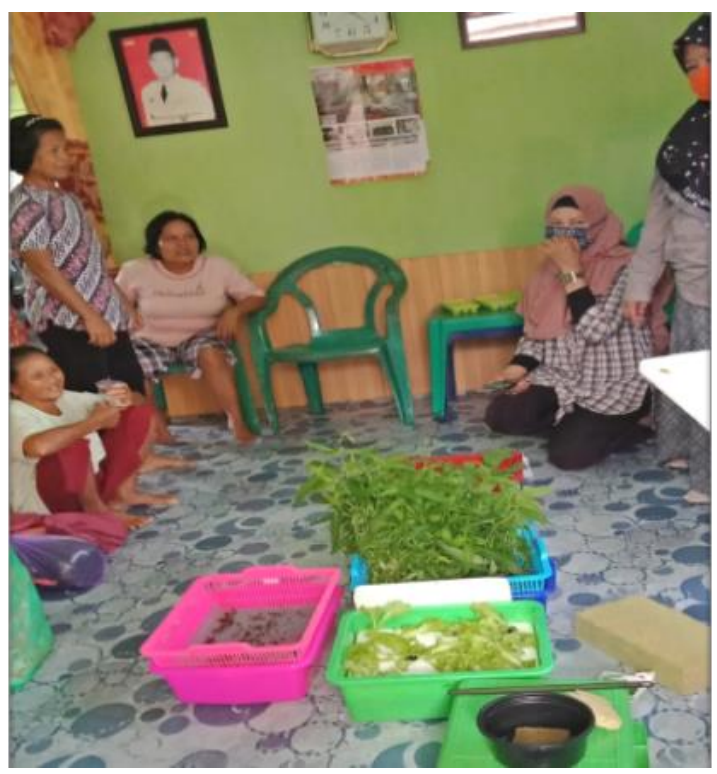

Gambar 2. Sosialisasi kepada masyarakat Mungku Baru

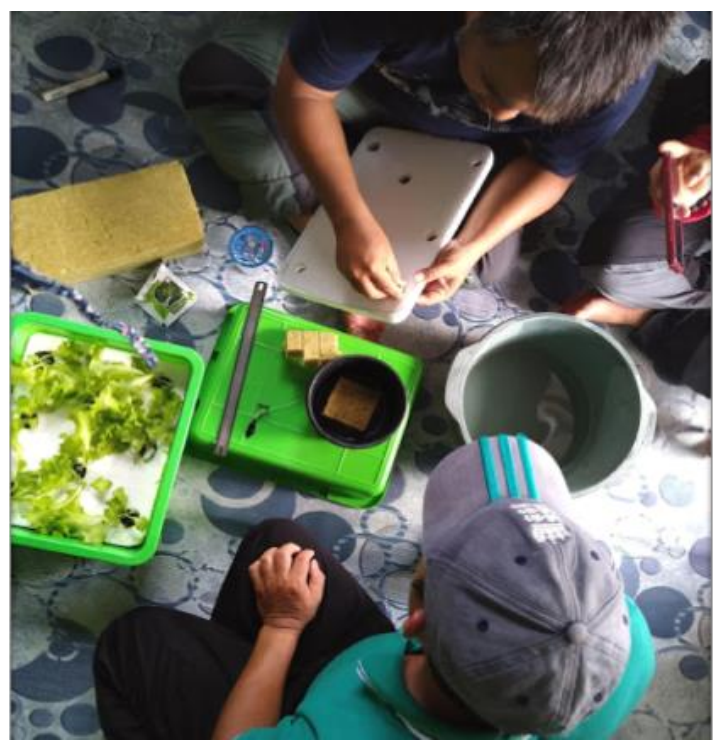

Gambar 3. Kegiatan pelatihan

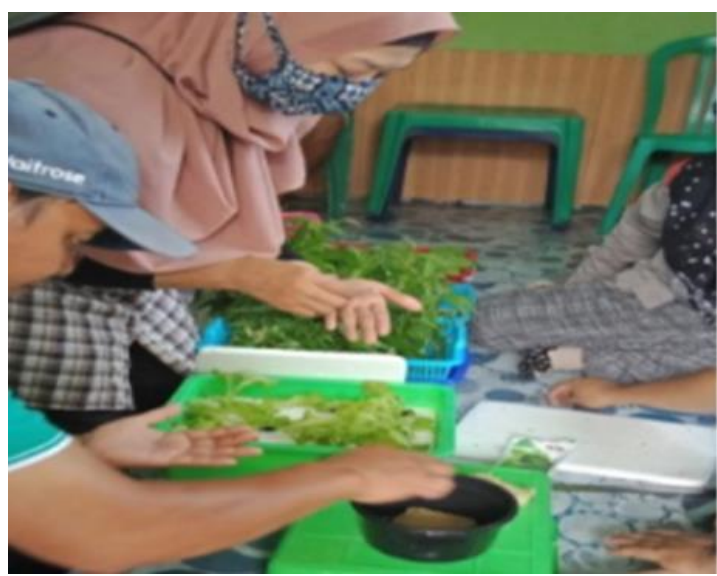

Gambar 4. Kegiatan pelatihan

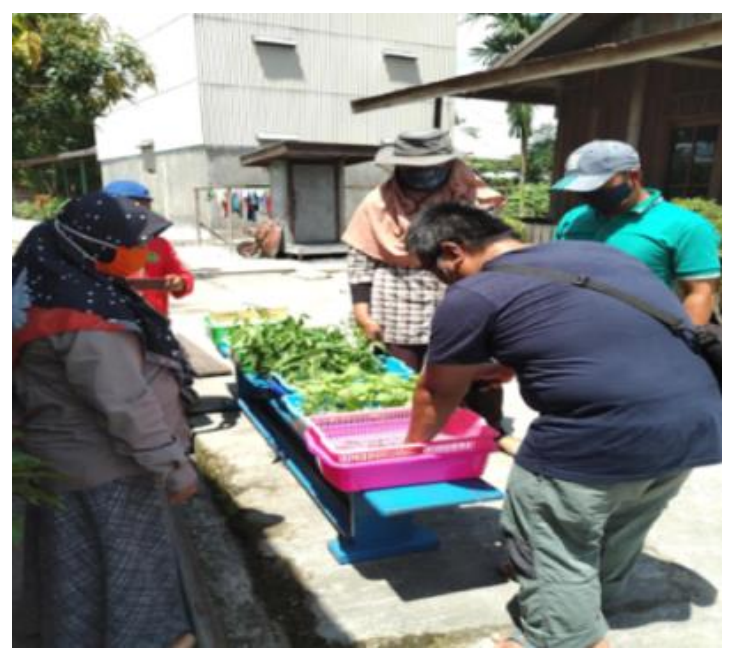

Gambar 5. Kegiatan monitoring

\section{KESIMPULAN}

Hasil kegiatan ini masyarakat sudah dapat menyiapkan tempat hidroponik, dilanjutkan penyiapan media hidup tanaman, menyemai bibit, menanam bibit dan membuat larutan hidroponik secara langsung, serta mereka mengetahui dosis penggunaan larutan nutrisi hidroponik dalam pengaplikasiannya. Masyarakat melakukan budidaya sayuran dengan metode hidroponik sederhana yang diletakkan di teras rumah dan pekarangan rumah dengan jenis sayuran yang mudah ditanam, cepat panen dan mudah dalam pemeliharaannya. Sayuran yang dipanen baru dimanfaatkan sebatas kebutuhan keluarga saja atau konsumsi rumah tangga. Budidaya hidroponik sayuran di pekarangan dapat mendukung ketahanan pangan terutama di masa pandemi Covid-19. Tindak lanjut dari kegiatan pengabdian kali ini adalah perlu adanya pelatihan pembuatan pupuk organik dengan menggunakan bahan lokal yang ada di Mungku Baru untuk memenuhi kebutuhan nutrisi tanaman atau pupuk untuk budidaya tanaman sayur-sayuran secara hidroponik agar masyarakat dapat memenuhi kebutuhan pupuk secara mandiri. 


\section{UCAPAN TERIMA KASIH}

Ucapan terima kasih disampaikan kepada LP2M Universitas Muhammadiyah Palangkaraya yang telah membantu pendanaan dan sarana pada kegiatan pengabdian Kepada masyarakat pada tahun anggaran 2019/2020.

\section{REFERENSI}

Dwiprabowo, H., Effendi, R., Hakim, I., Bangsawan, I. 2011. Kontribusi Kawasan Hutan Dalam Menunjang Ketahanan Pangan: Studi Kasus Propinsi Jawa Barat. Jurnal Analisis Kebijakan Kehutanan. 8(1):47-61. https://doi.org/10.20886/jakk.2011.8.1.47-61

Hanafi, N., Fahruni, F., Maimunah, S. 2017. Sosialisasi Pemanfaatan Hasil Hutan Bukan Kayu (HHBK) Sebagai Salah Satu Bentuk Pengelolaan KHDTK Kota Palangka Raya. PengabdianMu: Jurnal Ilmiah Pengabdian kepada Masyarakat. 2(1):31-36. https://doi.org/10.33084/pengabdianmu.v2i 1.117

Hidayati, N., Rosawanti, P., Arfianto, F. 2016. Pemanfaatan lahan pekarangan sebagai penghasil sayur-sayuran secara hidroponik di Kelurahan Tanjung Pinang Kota Palangka Raya. PengabdianMu: Jurnal Ilmiah Pengabdian kepada Masyarakat.1(2):85-90.

Jusriadi, A., Kamaluddin, L.A., Aljurida, A. 2020. Manajemen Mitigasi Krisis Pangan di Era Pandemi Covid 19. Journal of Governance and Local Politics (JGLP). 2(2):216-227. https://doi.org/10.47650/jglp.v2i2.96

Kusumaningtyas, R., Chofyan, I. 2013. Pengelolaan Hutan Dalam Mengatasi Alih Fungsi Lahan Hutan Di Wilayah Kabupaten Subang. Jurnal Perencanaan Wilayah dan Kota. 13(2):1-11. https://doi.org/10.29313/jpwk.v13i2.1389

Purnama, A., Afitah, I. 2021. Motivasi Masyarakat Terhadap Pengelolaan KHDTK Mungku Baru, Palangka Raya. Anterior Jurnal. 20(2):4349.

https://doi.org/10.33084/anterior.v20i2.2162

Resmeiliana, I., Sofyan, K., Achmadi, S.S. 2014. Karakteristik Asam Resin Kopal Agathis loranthifolia Sukabumi (Characteristic Resin Acid of Kopal Agathis loranthifolia Sukabumi). Jurnal Sains Terapan: Wahana Informasi dan Alih Teknologi Pertanian. 4(2):1317. https://doi.org/10.29244/jstsv.4.2.13-17

Suryana, A. 2014. Menuju Ketahanan Pangan Indonesia Berkelanjutan 2025: Tantangan Dan Penanganannya. Forum Penelitian Agro Ekonomi. 32(2):123-135. http://dx.doi.org/10.21082/fae.v32n2.2014.1 23-135

Yuliana. 2020. Corona virus diseases (Covid-19): Sebuah tinjauan literatur. Wellness and Healthy Magazine. 2(1):187-192. https://doi.org/10.30604/well.95212020

Zheng, J. 2020. SARS-CoV-2: an Emerging Coronavirus that Causes a Global Threat. International Journal of Biological Sciences. 16(10):1678-1685. https://dx.doi.org/10.7150/ijbs.45053 